\title{
Principals' Use of Student Mentorship Programmes and Students' Discipline in Secondary Schools in Machakos County, Kenya
}

\author{
Wambua, Patrick $M$. \\ Doctor of Education Student, University of Nairobi, Kenya \\ Kalai, Jeremiah M., PhD \\ Okoth, Ursula, A. PhD \\ Lecturer, School of Education, University of Nairobi, Kenya
}

Doi: 10.19044/esj.2017.v13n28p38 URL:http://dx.doi.org/10.19044/esj.2017.v13n28p38

\begin{abstract}
Studies have advocated for participatory governance in education (Kindiki, 2009, Tikoko\& Kiprop, 2011). There is however a dearth of literature on use student mentoring in relation to discipline. The purpose of this study was investigating principals' use of student mentorship programmes and students' discipline in secondary schools in Machakos County, Kenya. The study sought to establish the focus of student mentoring and determine significant relationships existed between principals' use of successful alumni, mentoring on ethical living and students' discipline in secondary schools. The study used systems theory by Ludwig Bartalanffy which postulates that schools are part of the environment in which they operate and influence and get influenced by other systems. Questionnaires for principals and student leaders were used. Cross-sectional survey design was adopted with a target population of 354 secondary schools principals and 4602 student leaders. Probability sampling was employed and stratified proportionate random sampling was used. A sample of 118 secondary school principals and 1534 student leaders were sampled and the return rate consisted of 101(85.6\%) principals, 100 teachers (100\%) and 1433(93.4\%) student leaders. Frequencies, percentages and Means were used to compare various forms of mentoring while correlation coefficients were used to determine the strengths of the association between the various participatory practices and establish if statistically significant or not. Student mentoring was practised in 66.3 per cent of schools with attendant reduced cases of indiscipline. There was a strong correlation between use of successful alumni, mentoring on academic excellence, mentoring on ethical living and student discipline.
\end{abstract}


Keywords: Peer mentoring, student discipline, discipline management

\section{Introduction}

Mentoring is generally regarded as a learning process where helpful, personal, and reciprocal relationships are built with a view to focusing on achievement and emotional support. The persons under mentorship (mentees) acquire skills and values through conversations with more experienced mentors who share knowledge and skills that can be incorporated into their thinking, practice and their value systems. According to Schwarts (1991), student affairs professionals provide emotional support by helping the students cope with feelings of isolation, anger and frustration, which could arise from their day to-day academic and social interactions and experiences. Mentorship programmes could be at the level of seniors whose experiences help mentees chart pathways for their own lives relying heavily on their more experienced superiors. Similarly, mentoring could be undertaken by peers whose experiences are not significantly different. A case in point is where senior students provide different forms of support to junior students. Mentoring focuses on diverse needs ranging from psychological, spiritual, professional, economic and educational needs (Malona, 2001).

The major issues and components for mentoring are on study skills, peer pressure not to do drugs, premarital sex, skip classes but to stick to the narrow which includes adherence to school dress code, being respectful and gentle (Makinde, 1990). In the Kenyan scene, student mentoring helps schools to meet academic and social goals. The academic goals revolve around academic excellence, being retained in school, ensuring progression and adhering to social codes and general etiquette. Online resources support peer mentoring on the understanding that school-based programmes on mentoring engage young people at their very levels and focusing on their aspirations so that they are facilitated to acquire skills, attitudes to cope with life hurdles effectively (http://www.safehealthyschools.org/youth/mentoring_program.htmRetrieved: $\quad 14^{\text {th }}$ December, 2007).

Belia (2000) avers that mentors need to reduce adolescence risk behaviour such as drugs, smoking and teenage sex. School with well mentoring programmes, whether by seniors or by peers are likely to produce more confident students, better focus, self-confidence and firmness on personal decision making. Mentorship integrates students in the school and this improves their sense of being connected. Mentors serve as role models towards success, encouragement and hand of oneness to students.

Mentoring programmes combat high dropout rates and encourage retention. It directs students on career paths, role models and implicitly helps students navigate school system. A study by Medosa (2010) indicates that 
mentorship has positive impact on student retention. The study by Medosa further observed that 94 per cent of those who went through mentoring programmes finished education course. Mentors play this great role by igniting the unrealised potentials in students. We are going to make manifest the glory of God is within us (Mandela, 1994). The mentor should feel oneself as an adviser, encourager, analyser and not a decision maker. The student needs to be agreeable and value advice in order to know the world around them, their origins, the present circumstances and their ultimate goal. The need for mentorship is more evident since new students need to familiarize to the new culture. In absence of structured mentorship programmes any student can be the source of transferring new experiences and expectations. It involves the guidance to achieve academic excellence, better and promising careers, ethical living, etiquette, self-awareness, leadership skills and aspirations, assertiveness and respect of diversity. Mentorship as postulated by (Chineshe, 2009) involvement in the schools generates support from the school community.

A study by Sticker and Palmer (2003) found that effectively mentored students tended to have higher achievement levels, scored higher on self-control measures, self-concept, higher and posted lower cases of drop out. Mentorship enhances participants capacity to initiate positive changes in the schools which has knock-on effective on factors that tend to lower the quality of school outcomes such as truancy, disruptive behaviours and low academic achievements. Mentors play a significant role in shaping students personality patterns, their crucial partners in school endeavour to develop and mould students. Mentors involvement has a positive impact on student achievement, success and discipline while in school. There is a mutual gain when mentors and school principals partner to upgrade student scholastic and social life. Mentoring can be done by student peers or schools can engage alumni in mentoring the students on tenets of excellence, discipline, resilience, community service, aspects that can engage students to the point of making them disciplined. The alumni have the history of the schools, its discipline patterns and even its academic trends. Such history can be a point of connection making it easy for alumni to easily connect with students and thereby enhance levels of discipline. Mentorship and discipline correlate and they exist in schools inform of family tree. Mentorship inculcates productive relationship, environment that allows students and community interact harmoniously (Hellwingol, 2000).

\section{Statement of the problem}

A number of studies have attested to the need for participatory governance in general and involvement of students in educational institutions in particular (Kindiki, 2009, Mulwa, 2014). Involvement in governance 
either through policy directives or use of students' peers can be a strategy of addressing various forms of indiscipline. This is important to reduce loss of property, loss of study time and loss of student lives (Matungulu Sub-County Director of Education's Office, 2013). In Machakos Sub-County, 15 secondary went on rampage (CDE-MOE Machakos, 2015). In 2014, the same trend followed in Matungulu Sub-County, Masinga Sub-County, Machakos Sub-County. Kangundo Sub-County with fatal results Students lost their lives and many left with scars and trauma. In Term two 2015, a record 31 schools in Machakos County had gone on strike in a span of a month (Machakos County Director of Education, 2015). Although educational policy makers and practitioners have employed different mechanisms of reducing indiscipline in secondary schools (Kindiki, 2009, Tikoko \& Kiprop, 2011\& Mulwa, 2014), there is a dearth of literature and empirical evidence exploring use of student mentoring as a mechanism of reducing student indiscipline in secondary schools. This study therefore focused on various forms of student mentoring and how they relate to status of student discipline in secondary schools in Machakos County, Kenya. The study would inform practitioners and policy makers on possible benefits of mentoring as a discipline management strategy.

\section{Purpose of the study}

This study sought to investigate the influence of principals' mentorship practices on students' discipline in secondary schools in Machakos County, Kenya.

\section{Research objectives}

To fulfil the purpose of the study, the following objectives were explored:

i) To establish the focus of students' mentorship programmes conducted by secondary school principals as a measure of curbing indiscipline in Kenya

ii)To determine whether significant relationship exists between principals' use of successful alumni and students' discipline in secondary schools

iii)To establish whether significant relationship exists between mentoring on academic excellence and secondary school students' discipline

iv)To establish whether significant relationship exists between mentoring on ethical living and students' discipline in secondary schools

\section{Research design}

The descriptive survey design was adopted in conducting the study. According to Creswell (2012), a descriptive survey design reports the way things are through a systemic collection of data from members of a given population. In this design, the researcher examined naturally existing 
relationships in which treatment is done through natural ways rather than manipulation of persons or figures (Martens, 2010).

\section{Target population}

Orodho (2005) defines target population as all the items or people under consideration in any field of inquiry. Kasomo (2006) defines target population as the entire objects and events or group of people which is the object of research and about which the researcher wants to determine some characteristics. The County has 356 schools translating to 356 principals.

\section{Sample size and sampling procedures}

A sample is a subset of a particular population that represents the whole. Where the population is heterogeneous, a big sample as possible should be taken (Kothari, 2011).There are 356 principals in Machakos County and for a descriptive research, 30 per cent will be an effective representation (Creswell, 2012).This translates to 118 principals, 108 teachers and each school presented 13 student leaders. Since there are sub-groups involved stratified sampling was applied and the sample size was increased to ascertain appropriate representation and avoid sampling error. Stratified sampling was used for the schools to ascertain that categories to do with national schools, extra-county schools, county schools and day schools were represented. The schools comprise boys schools, girls boarding, mixed day and boarding and day schools. Kasomo (2006) observes that purposive sampling helps to increase accuracy.

\section{Research instruments}

Questionnaires were used for the collection of data from principals and student leaders. The researcher developed the instruments. Creswell (2012), Mugenda (2008), and Krathwohl (1998) observed that questionnaires offer a considerable advantage in administration and enable the researcher to collect relatively wide range of information in a short period. They also enhance generation of more standardized data. The study used closed questionnaires for principals and student leaders with a few open-ended ones to obtain more data. The questionnaires had a section focusing on background data and sections focusing on each of the study variables.

\section{Research design}

The descriptive survey design was adopted in conducting the study. According to Mugenda and Mugenda (2008), a descriptive survey design reports the way things are through a systemic collection of data from members of a given population. In this design, the researcher examined naturally existing relationships in which treatment is done through natural 
ways rather than manipulation of persons or figures (Martens, 2010). Machakos County had many schools and descriptive survey design was used to establish the state of students discipline in secondary schools.

\section{Research instruments}

Questionnaires were used for the collection of data from principals and student leaders. The researcher developed the instruments. Creswell (2012) observes that questionnaires offer a considerable advantage in administration, enable researchers to collect relatively wide range of information in a short period and they are also economical in costs. They also enhance generation of more standardized data.

\section{Data analysis techniques}

To establish the focus of mentoring among secondary students, group Means were obtained and cross-tabulated with incidences of indiscipline. To determine whether significant relationships existed between the independent and the dependent variables, Pearson Correlation coefficients were obtained at 95 per cent level of significance. The ranking of the coefficients was based on strong relationship to no relationship between the independent and dependent variables.

\section{Instrument return rate}

From a total of 118 questionnaires administered to secondary school principals, 101 were returned translating to a return rate of 85.6 per cent, while all the 100 interview schedules $(100 \%)$ administered to teachers were usable. Out of the 1534 questionnaires administered to students, 1433 of them $(93.4 \%)$ were returned and useful for the study.

\section{Discussion of findings}

The first objective sought to establish the areas of focus by secondary school principals in student mentoring as a strategy of reducing student indiscipline among secondary school students. Table 1 presents the findings on areas of focus in student mentoring

Table 1: Areas of focus in student mentoring

\begin{tabular}{|c|c|c|c|}
\hline Area of mentoring & $\mathrm{N}$ & Mean & Std. Deviation \\
\hline $\begin{array}{c}\text { Mentoring of students on academic excellence influences } \\
\text { student discipline }\end{array}$ & 101 & 4.2277 & .89310 \\
\hline Mentoring of students on careers influences student discipline & 101 & 4.0000 & .83666 \\
\hline $\begin{array}{l}\text { Mentoring of students on self-awareness influences student } \\
\text { discipline }\end{array}$ & 101 & 4.0000 & .83666 \\
\hline $\begin{array}{c}\text { Mentoring of students on leadership influences student } \\
\text { discipline }\end{array}$ & 101 & 3.9307 & .88609 \\
\hline $\begin{array}{c}\text { Mentoring of students on ethical living influences student } \\
\text { discipline }\end{array}$ & 101 & 3.9208 & .83286 \\
\hline $\begin{array}{l}\text { Mentoring of students on respect of diversity influences student } \\
\text { discipline }\end{array}$ & 101 & 3.8515 & .89873 \\
\hline
\end{tabular}


The findings indicated that the areas of student mentoring that were highly associated with reduction in indiscipline cases were mentoring on academic excellence $(M=4.22)$, self-=awareness $\quad(M=4.00)$, careers $(M=4.00)$, leadership ( $M=3.93)$, ethical living $(M=3.92)$ whereas mentoring on respect of diversity was perceived to have the least influence on student discipline. The mentoring of students on the above areas of their interest was likely to reduce indiscipline cases on account of creating a sense of purpose, making students to be focused both on academics as well as other spheres of life. This could create an all-round discipline and a drive for excellence, which could preclude any focus on petty student offences. Mentoring on academic excellence appears a key driver to creating a culture of order which is a prerequisite to discipline. Mentoring of students on respect of diversity appeared to have the least influence on student discipline with a Mean of 3.85. Although accommodating diversity is important, it may not be directly related to issues relating to student unrests and discipline. The foregoing findings are supported by Pita, Ramirez, Joacin, Prentice and Clarke (2013) who conducted a study among undergraduate students that demonstrated that mentoring provided an exceptionally positive experience for students. The same position was supported by Seymour et al. (2004). In addition to embracing diversity, students are socialised into other people's cultures and backgrounds. The study also explored ethical living, which is about integrity and pursuing the common good. This entails teaching the students about the best practices, norms and societal expectations. Mentorship on careers is about the rationale of being in school and the available career paths to follow. This confirms that mentorship is so critical in maintaining school order and needs strong back up. The study established that mentorship enhanced those aspects and is in agreement with Denni and bobby (2006) who state that mentoring requires wide culture that lends active support to programmes that enhance quality achievements. The second objective sought to determine whether significant relationship existed between principals' use of mentoring by successful alumni and students on students' discipline in secondary schools.

Table 2: Correlation between students mentoring by alumni and discipline

\begin{tabular}{|ccc|}
\hline $\begin{array}{c}\text { Prevalence of strikes and demonstrations in the last } \\
\text { three years }\end{array}$ & $\begin{array}{c}\text { Pearson } \\
\text { Correlation }\end{array}$ & $-.094^{* * *}$ \\
& Sig. (2-tailed) & .000 \\
\hline $\begin{array}{c}\text { Extent to which theft of students' items has been } \\
\text { prevalent for the last three years }\end{array}$ & $\begin{array}{c}\text { Pearson } \\
\text { Correlation }\end{array}$ & -.039 \\
\cline { 2 - 3 } & Sig. (2-tailed) & .133 \\
\cline { 2 - 3 } & $\mathrm{N}$ & 1433 \\
\hline Prevalence of sneaking out of school in the last three years & Pearson & $-.068^{*}$ \\
\hline
\end{tabular}




\begin{tabular}{|c|c|c|}
\hline & Correlation & \\
\hline & Sig. (2-tailed) & .010 \\
\hline & $\mathrm{N}$ & 1433 \\
\hline \multirow[t]{5}{*}{$\begin{array}{l}\text { Prevalence of drugs and substance abuse in the last } \\
\text { three years }\end{array}$} & $\begin{array}{c}\text { Pearson } \\
\text { Correlation }\end{array}$ & $-.058^{*}$ \\
\hline & Sig. (2-tailed) & .028 \\
\hline & $\mathrm{N}$ & 1433 \\
\hline & Sig. (2-tailed) & .943 \\
\hline & $\mathrm{N}$ & 1433 \\
\hline \multirow[t]{3}{*}{$\begin{array}{c}\text { Prevalence of defiance of authority in the last three } \\
\text { years }\end{array}$} & $\begin{array}{c}\text { Pearson } \\
\text { Correlation }\end{array}$ & -.047 \\
\hline & Sig. (2-tailed) & .075 \\
\hline & $\mathrm{N}$ & 1433 \\
\hline \multirow[t]{3}{*}{ Prevalence of missing of lessons by students } & $\begin{array}{c}\text { Pearson } \\
\text { Correlation }\end{array}$ & -.051 \\
\hline & Sig. (2-tailed) & .053 \\
\hline & $\mathrm{N}$ & 1433 \\
\hline
\end{tabular}

The findings of the study demonstrated a strong relationship between use of successful alumni and reduced incidences of prevalence of strikes and demonstrations $\left(-.094^{* *}\right)$, sneaking out of school $\left(-.068^{*}\right)$ and prevalence of drugs and substance abuse $\left(-.058^{*}\right)$ in the last three years. The strongest of the relationship was on the use of alumni and reduction of strikes and demonstrations whereas the data indicated a weak relationship between use of alumni and incidences of students' failure to attend to duties. The relationship could be attributed to the role modelling function of the alumni who could also reinforce positive aspects of school culture. Similarly, successful alumni epitomise the aspirations of the students and also reinforce the belief that success is possible within the context of their given school.

The study however established a weak relationship between mentorship by successful alumni and prevalence of missing of lessons by students and defiance of authority. The weak relationship between use of successful alumni and students' failure to attend to duties could be a natural apathy to chores informed by current society's engagement of domestic helps and not necessarily outright sign of total breakdown of discipline. The findings of this study are supported by Mulwa (2014) who observed that peer counselling and mentoring created a sense of discipline, cohesion and tended to make students more focused not only academically but also in many spheres of life. The next null hypothesis stated that there was no significant relationship between mentoring students on academic excellence and their discipline. The findings, obtained from principals of secondary schools are presented in Table 3. 
Table 3: Correlation between mentoring of students on academic excellence and discipline: Principals' perspectives

\begin{tabular}{|c|c|c|}
\hline Prevalence of missing of lessons by students & $\begin{array}{c}\text { Pearson } \\
\text { Correlation }\end{array}$ & $-.075^{* *}$ \\
\hline \multirow{6}{*}{$\begin{array}{c}\text { Prevalence of strikes and demonstrations in the } \\
\text { last three years }\end{array}$} & Sig. (2-tailed) & .005 \\
\hline & $\mathrm{N}$ & 1433 \\
\hline & $\mathrm{N}$ & 1433 \\
\hline & $\begin{array}{l}\text { Pearson } \\
\text { Correlation }\end{array}$ & $-.058^{*}$ \\
\hline & Sig. (2-tailed) & .027 \\
\hline & $\mathrm{N}$ & 1433 \\
\hline \multirow[t]{3}{*}{$\begin{array}{l}\text { Prevalence of failure to attend duties in the last } \\
\text { three years }\end{array}$} & $\begin{array}{l}\text { Pearson } \\
\text { Correlation }\end{array}$ & $-.056^{*}$ \\
\hline & Sig. (2-tailed) & .033 \\
\hline & $\mathrm{N}$ & 1433 \\
\hline $\begin{array}{c}\text { Prevalence of sneaking out of school in the last } \\
\text { three years }\end{array}$ & $\begin{array}{c}\text { Pearson } \\
\text { Correlation }\end{array}$ & $-.055^{*}$ \\
\hline \multirow{5}{*}{$\begin{array}{l}\text { Prevalence of drugs and substance abuse in the } \\
\text { last three years }\end{array}$} & Sig. (2-tailed) & .036 \\
\hline & $\mathrm{N}$ & 1433 \\
\hline & $\begin{array}{c}\text { Pearson } \\
\text { Correlation }\end{array}$ & -.050 \\
\hline & Sig. (2-tailed) & .057 \\
\hline & $\mathrm{N}$ & 1433 \\
\hline
\end{tabular}

The findings indicated a strong relationship between mentoring of students on academic excellence and low incidences missing of lessons by students $\left(-.075^{* *)}\right.$, theft of students' items $\left(-.069^{* * *)}\right.$ and failure to attend duties $\left(-.056^{*}\right)$. There is a correlation between with reduction on prevalence of strikes and demonstrations, failure to attend to duties and sneaking at $\mathrm{p}<-$ $0.058-, 0.056,-0.055$ respectively. There is little correlation between mentorship with failure to attend to duties, drugs and substance abuse. This indicates that mentorship had a great role in diminishing theft of student items as may not want to find themselves with discipline cases and missing lessons, mentoring on academic excellence minimises theft in schools. Mentorship reduces strikes in schools as student's unrest and discipline cases undermine the quality of education. Mentorship on academic excellence correlates with decline in sneaking out of school for avoidance of suspension and related punishments. Absenteeism from class is a major discipline issue in schools. Reid (2006) in his study reported a positive correlation between performance and school attendance which confirms Ovell (2001) that discipline in schools is essential for effective learning, good teacher relations and peer adjustment. The table presents the correlations that exist between mentorship on careers positions and the discipline in the sampled schools and the related information. The next objective sought to determine whether 
significant relationship existed between career mentoring and students' discipline.

The next null hypothesis stated that there is no significant relationship between mentoring students on ethical living and their discipline (as demonstrated by incidences of indiscipline reported). The findings are resented in Table 4

Table 4: Correlation between mentoring of students on ethical living and students' discipline

\begin{tabular}{|c|c|c|}
\hline \multirow[t]{3}{*}{$\begin{array}{l}\text { Prevalence of strikes and demonstrations in the last three } \\
\text { years }\end{array}$} & $\begin{array}{c}\text { Pearson } \\
\text { Correlation }\end{array}$ & $-.136^{* *}$ \\
\hline & Sig. (2-tailed) & .000 \\
\hline & $\mathrm{N}$ & 1433 \\
\hline \multirow{3}{*}{$\begin{array}{c}\text { Prevalence of drugs and substance abuse in the last three } \\
\text { years }\end{array}$} & Pearson Correlation & $-.130^{* *}$ \\
\hline & Sig. (2-tailed) & .000 \\
\hline & $\mathrm{N}$ & 1433 \\
\hline \multirow[t]{3}{*}{ Prevalence of missing of lessons by students } & Pearson Correlation & $-.107^{* *}$ \\
\hline & Sig. (2-tailed) & .000 \\
\hline & $\mathrm{N}$ & 1433 \\
\hline \multirow[t]{3}{*}{ Prevalence of sneaking out of school in the last three years } & Pearson Correlation & $-.096^{* *}$ \\
\hline & Sig. (2-tailed) & .000 \\
\hline & $\mathrm{N}$ & 1433 \\
\hline \multirow[t]{3}{*}{ Prevalence of defiance of authority in the last three years } & Pearson Correlation & $-.083^{* *}$ \\
\hline & Sig. (2-tailed) & .002 \\
\hline & $\mathrm{N}$ & 1433 \\
\hline \multirow[t]{3}{*}{ Prevalence of failure to attend duties in the last three years } & Pearson Correlation & $-.083^{* *}$ \\
\hline & Sig. (2-tailed) & .002 \\
\hline & $\mathrm{N}$ & 1433 \\
\hline \multirow{3}{*}{$\begin{array}{l}\text { Extent to which theft of students' items has been prevalent } \\
\text { for the last three years }\end{array}$} & Pearson Correlation & -.028 \\
\hline & Sig. (2-tailed) & .298 \\
\hline & $\mathrm{N}$ & 1433 \\
\hline
\end{tabular}

At a level of 95 per cent confidence level, the study established a strong relationship between mentoring on ethical living and reduced cases of strikes and demonstrations, drugs and substance abuse, missing of lessons by students, sneaking out of school, failure to attend duties $\left(-.083^{* *}\right)$ and defiance of authority $\left(-.083^{* *}\right)$ as reported by students in the past three years. However, theft of students' items had a weak relationship with mentoring on ethical living. The correlation coefficients indicate that there exists a strong and a significant relationship between ethical living and students discipline as evidenced by lowered cases of reduction of prevalence of strikes and demonstrations, failure to do duties, defiance of authority, sneaking out of school, drugs and substance abuse and missing of lessons as reflected in $\mathrm{p}<-$ $0.136,-0.083,-0.083 .0 .096 .-0.130$, and $-.107^{* *}$. The correlation is low with theft of students at $p<0.028$. The study finding concurs with Mumo (2004) in her research on students' unrest and discipline cases that links student discipline with academic and social success. The cited findings support the sentiments expressed by Eshiwani (1993) who noted that frequent student support can be a form of arresting possible damage that can be visited on 
schools through student unrests. Such unrests lead to loss of property and valuable study time is lost. Mentorship on ethical living lowers the incidents of defiance by students. This is confirmed by a study by Penn (2010) on academic mentoring in secondary schools who espouses that a variety of interventions been established to help those trapped in the abuse and academic deficiencies. Home circumstances including lack of adult support leaves them vulnerable to cope with emotional and social situations a position held by Carter (2004) and Johnson (2008); a position supported by Daloz (2004) that caring and competent mentors in a one-on-one setting can be help students with challenges to overcome adversity.

The next null hypothesis stated that there was no significant relationship between mentoring of students on self-awareness and students' discipline. Mentoring on self-awareness refers to recognising, respecting cultural and gender differences, establishing positive and trusting relationships, understanding one's strengths and weaknesses and building rapport between the student and the mentor. The findings are reflected in Table 5.

Table 5: Correlation between mentoring students on self-awareness and discipline

\begin{tabular}{|c|c|c|}
\hline \multicolumn{3}{|l|}{ Mentoring of students on self-awareness } \\
\hline \multirow[t]{3}{*}{ Prevalence of missing of lessons by students } & $\begin{array}{c}\text { Pearson } \\
\text { Correlation }\end{array}$ & $-.123^{* *}$ \\
\hline & Sig. (2-tailed) & .000 \\
\hline & $\mathrm{N}$ & 1433 \\
\hline \multirow[t]{3}{*}{ Prevalence of defiance of authority in the last three years } & $\begin{array}{c}\text { Pearson } \\
\text { Correlation }\end{array}$ & $-.102^{* *}$ \\
\hline & Sig. (2-tailed) & .000 \\
\hline & $\mathrm{N}$ & 1433 \\
\hline \multirow[t]{3}{*}{ Prevalence of drugs and substance abuse in the last three years } & $\begin{array}{l}\text { Pearson } \\
\text { Correlation }\end{array}$ & $-.098^{* *}$ \\
\hline & Sig. (2-tailed) & .000 \\
\hline & $\mathrm{N}$ & 1433 \\
\hline \multirow[t]{3}{*}{ Prevalence of sneaking out of school in the last three years } & $\begin{array}{c}\text { Pearson } \\
\text { Correlation }\end{array}$ & $-.096^{* *}$ \\
\hline & Sig. (2-tailed) & .000 \\
\hline & $\mathrm{N}$ & 1433 \\
\hline \multirow[t]{3}{*}{ Prevalence of strikes and demonstrations in the last three years } & $\begin{array}{c}\text { Pearson } \\
\text { Correlation }\end{array}$ & $-.059^{*}$ \\
\hline & Sig. (2-tailed) & .026 \\
\hline & $\mathrm{N}$ & 1433 \\
\hline \multirow[t]{3}{*}{ Prevalence of failure to attend duties in the last three years } & $\begin{array}{l}\text { Pearson } \\
\text { Correlation }\end{array}$ & $-.053^{*}$ \\
\hline & Sig. (2-tailed) & .045 \\
\hline & $\mathrm{N}$ & 1433 \\
\hline \multirow[t]{3}{*}{$\begin{array}{l}\text { Extent to which theft of students' items has been prevalent for } \\
\text { the last three years }\end{array}$} & $\begin{array}{c}\text { Pearson } \\
\text { Correlation }\end{array}$ & -.032 \\
\hline & Sig. (2-tailed) & .231 \\
\hline & $\mathrm{N}$ & 1433 \\
\hline
\end{tabular}


The data analysis established a strong Pearson correlation coefficient as $\mathrm{p}<-0.102,-0.096,-0.098,-0.123$ respectively. It implies that the more students became self-aware, the lower the cases of strikes and demonstrations and attendance to duty. The findings suggest that the more the cases of student mentoring on self-awareness, the less the occurrence of strikes. This could mean student mentoring leads to independence, autonomy and being more accountable for their actions. The study findings indicate a strong positive relationship between student mentorship and reduction in the perennial problem of students' unrest. This is supported by Webster (2005) who observed that mentoring fosters a caring and supportive relationship for students and provides clear guidelines and expectations. Mentorship on selfawareness correlates positively with attendance to classes. This confirms study by Crutcher (2007) that mentors need to set firm and consistent limits. The findings concur with a related study by Epstein (2001) who noted that students are moulded to reflect the societal values. Drugs and substance abuse results to anti-social behaviours which culminate into discipline cases and criminal activities. This confirms study by Penn (2010) that mentors to set goals and work through success plan.

The next null hypothesis stated that there is no significant relationship between mentoring of students on embracing diversity and their discipline. Diversity is the quality and strategies for engaging students to be accommodative of varying views, ideologies, cultural values, belief systems and religious tolerance. The findings are resented in Table 6

Table 6: Correlation between mentoring students on diversity and discipline

Mentoring of students on respect of diversity

\begin{tabular}{|c|c|c|}
\hline \multirow[t]{3}{*}{$\begin{array}{l}\text { Prevalence of strikes and demonstrations in the last } \\
\text { three years }\end{array}$} & $\begin{array}{c}\text { Pearson } \\
\text { Correlation }\end{array}$ & $-.170^{* *}$ \\
\hline & Sig. (2-tailed) & .000 \\
\hline & $\mathrm{N}$ & 1433 \\
\hline \multirow[t]{3}{*}{$\begin{array}{l}\text { Prevalence of drugs and substance abuse in the last } \\
\text { three years }\end{array}$} & $\begin{array}{l}\text { Pearson } \\
\text { Correlation }\end{array}$ & $-.160^{* *}$ \\
\hline & Sig. (2-tailed) & .000 \\
\hline & $\mathrm{N}$ & 1433 \\
\hline \multirow[t]{3}{*}{ Prevalence of missing of lessons by students } & $\begin{array}{l}\text { Pearson } \\
\text { Correlation }\end{array}$ & $-.112^{* *}$ \\
\hline & Sig. (2-tailed) & .000 \\
\hline & $\mathrm{N}$ & 1433 \\
\hline \multirow[t]{3}{*}{$\begin{array}{c}\text { Extent to which theft of students' items has been } \\
\text { prevalent for the last three years }\end{array}$} & $\begin{array}{c}\text { Pearson } \\
\text { Correlation }\end{array}$ & $-.110^{* *}$ \\
\hline & Sig. (2-tailed) & .000 \\
\hline & $\mathrm{N}$ & 1433 \\
\hline \multirow[t]{3}{*}{$\begin{array}{l}\text { Prevalence of failure to attend duties in the last three } \\
\text { years }\end{array}$} & $\begin{array}{l}\text { Pearson } \\
\text { Correlation }\end{array}$ & $-.096^{* *}$ \\
\hline & Sig. (2-tailed) & .000 \\
\hline & $\mathrm{N}$ & 1433 \\
\hline
\end{tabular}




\begin{tabular}{ccc}
\hline $\begin{array}{c}\text { Prevalence of sneaking out of school in the last three } \\
\text { years }\end{array}$ & $\begin{array}{c}\text { Pearson } \\
\text { Correlation }\end{array}$ & $-.090^{* *}$ \\
\hline $\begin{array}{c}\text { Sig. (2-tailed) } \\
\text { Prevalence of defiance of authority in the last three years }\end{array}$ & .001 \\
& $\begin{array}{c}\text { Pearson } \\
\text { Correlation }\end{array}$ & 1433 \\
& Sig. (2-tailed) & $.065^{*}$ \\
& $\mathrm{~N}$ & 1433 \\
\hline
\end{tabular}

The findings indicate a strong correlation between mentoring of students on accommodating diversity and reduced cases of theft of student items, strikes and demonstrations, missing of classes (class attendance), defiance of authority, sneaking and substance abuse. The possible reasons for a strong relationship between reduced cases of indiscipline and counselling on ethical living could be that creating awareness on ethical living could make students conscious of right and wrong and therefore be socially enlightened and willing to toe the line.

\section{Conclusion}

i) The study concluded that use of successful alumni, organizing training sessions for peer educators is highly correlated with reduced cases of indiscipline among students in secondary schools.

ii)This study concluded that mentoring is a strong strategy of reducing various forms of student indiscipline and In addition, mentoring on academic excellence tended to create school ethos and culture that tended to foster open school climate that consequently reduced negative forms of discipline.

iii)The study further concluded that mentoring of students on ethical living was strongly correlated with reduced incidences of negative discipline. Mentoring tended to lead to inculcation of positive habits which could be passed from senior students to the junior ones, thereby reducing cases of indiscipline

\section{Recommendations}

Based on the research findings and conclusions of this study, the following recommendations are made:

i)The Ministry of Basic Education could formulate guidelines on mentorship not only of students but also of new teachers by their senior colleagues with a view to inculcating positive work ethics and behaviour

ii)To enhance inclusivity in educational institutions, the Ministry of Education can reconsider the quota system policy that tends to have students from similar localities being confined in their areas of origin, which could become a breeding ground for negative ethnicity. Similarly, national values need to be inculcated among students for enhanced national cohesion 


\section{Suggestions for further research}

i) This study recommends a duplication of the same study in more counties within the Republic of Kenya using more research instruments

ii) In addition, the recently introduced governance structures that involves students in governance at the level of Boards of Management may need to be more contextualised to the level of each school so that involvement in decision making is only on issues that directly affect students in their day-to-day operations

\section{References:}

1. African Virtual University (2016). Youth Engagement through Schools: Mentoring/Coaching Programs Module on Guidance and Counselling. $\quad$ Nairobi: http://www.safehealthyschools.org/youth/mentoring_program.htm

2. Amayo, G.N. (1994). International Institute for prevention of drug abuse: A Handbook for primary and secondary school teachers' guidelines in drug dependence preventive education. Nairobi: Lama Limited Printers.

3. Bajpai, S.R.\& Bajpai, R.C. (2014). Reliability and validity. International of medical sciences, public health, 3(1), 173-176.

4. Beirer, S. (2000). The potential of adult mentor in influencing high risk behaviour in adolescent; Archives.

5. Best, J. W. \& Kahn, J. V. (2005). Research in education, ninth edition. New Delhi: Prentice Hall of India.

6. Britton, T. \&Painne, L. (2005).Applying ideas from other countries. In $\mathrm{H}$. Porter (Ed) Teacher mentoring and induction. The state of the art and beyond: 225-237. CA: Thousand Oaks.

7. Carter, L. (2004). The sustaining effect study of compensatory and elementary education of research 13 (7) 4-13.

8. Creswell, .J. W (2012). Educational Research: planning, conducting and evaluating qualitative and quantitative research, $4^{\text {th }}$ edition. London: Pearson Research

9. Daloz, H. (2004). Why mentoring works. New York: Houghton Mifflin.

10. Edgar, J. \& Raizen, S. (2003). Comprehensive teacher induction system for early career learning. Dordrecht, Netherlands: Klumer Academic Publishers.

11. Epstein, J. L (2001). School, family and community partnerships preparing educators and improving schools, Boulder, Co: West view press.

12. Eshiwani, G.S. (1993). Education in Kenya since independence. Nairobi: East African Publishers., Kenya. 
13. Hellwing, B.A (2000). Exploring the college student body president leadership phenomenon published doctoral Dissertation University of North Colorado, Greenly Colorado. UMI No.9983074. Accessed on $14^{\text {th }}$ July 2017.

14. Hoover, E. (2005). In unlikely relationship chronicle of higher education 51 (38, A35-A36 Retrieved.) February 72008 from academic search premier data base $1720 \quad 81$ 25.Http:/chronical.com/article/unlikely-relationship/12584.

15. Ingersol, R.M. \& Smith, T.M. (2004).Impact of mentoring on teacher retention. What the Research says Denver Co. Education commission of states.

16. Kasomo, D. (2006). Research methods in humanities and education. Eldoret: Zapf chancery.

17. Kindiki, J. N. (2009). Effectiveness of boards of governors in curriculum implementation in Secondary schools in Kenya. The Educational Research Review, 4. Accessed on 23 ${ }^{\text {rd }}$ January, 2017.

18. Krathwohl, D.R. (1998).Educational \& Social science research: An integrated approach, Second edition. New York: Longman.

19. Makinde, O. (1990). Fundamental of Guidance. Atlanta Dallas: Houghton

20. Martens, D.M. (2010). Research and evaluation in education and psychology: Integrating diversity with quantitative, qualitative and mixed methods, third edition. Los Angeles: London: New Delhi: SAGE

21. Matungulu Sub-County Director of Education's Office (2013). Annual report, Ministry of Education. Matungulu: Unpublished annual report.

22. Mugenda, A. G. (2008). Social Science research: Theory and principles. Nairobi: Applied Research and Training Services.

23. Mulwa, J. K. (2014). Effects of principals' alternative disciplinary methods on students' discipline in public secondary schools in Kitui County, Kenya, unpublished $\mathrm{PhD}$ thesis, University of Nairobi.

24. Mungai, J.G. (2007). The role of head teachers in promoting drug abuse counselling among students in public secondary schools in Nyeri and Mbeere Districts, unpublished $\mathrm{PhD}$ thesis, Kenyatta University.

25. National Campaign Agency against Drug and Substance Abuse (NACADA, 2006). Drug and Substance Abuse in tertiary institutions in Kenya: A situational analysis. Nairobi: Government printer

26. Ndichu, D. (2005). Guidance and counseling, Handbook for schools. Nairobi: Career ventures. 
27. Orodho, J.A. (2005) Techniques of writing research proposals in education and social sciences second edition. Nairobi: Kanez Enterprise.

28. Penn, S. (2010). Academic mentoring in secondary schools. retrieved December 15，2010.htt://www.ehow.com/about6645242 Academic mentoring secondary school.html. Accessed on $25^{\text {th }}$ June, 2017.

29. Pita, M., Ramirez, C., Joacin, N. Prentice, S. \& Clarke, C. (2013). Five Effective Strategies for Mentoring Undergraduates: Students' Perspectives. Council on Undergraduate Research, Spring, Volume 33, Number 3.

30. Republic of Kenya (2001). Report of the taskforce on student discipline and unrest in secondary schools. Nairobi: Jomo Kenyatta Foundation.

31. Rue, N.J \& Byans, E.S (2006). Effects and assessment of students' involvement in campus governance in M. Miller \& D.P Nadler (EDS) student governance and institutional policy: formation and implementation pp (19-32). Connecticut: Information age publishing.

32. Schewaltz, H.L (1991): An interview study of formal student leaders' perception of an ethical conflict involving student president: Journal of college student development, 32: 446-455.

33. Seymour, E., Hunter, A.B., Laursen, S.L., \& Tracee, D.A. (2004). Establishing the benefits of research experiences for undergraduates in the sciences: first findings from a three-year study." Science Education 88 (4): 493-534.doi:10.1002/sce.10131

34. Pita, M., Ramirez, C., Joacin, N. Prentice, S. \& Clarke, C. (2013). Five effective strategies for mentoring undergraduates: students' perspectives, Council on Undergraduate Research, spring, Volume 33, Number 3.

35. Shein, E.H. (1988). Career dynamics matching individual and organizational

36. Goals. London: Addison Wesley.

37. Tikoko, B. J. \& Kiprop, C. J. (2011). . Extent of student participation in decision making in secondary schools in Kenya. International Journal of Humanities and Social Science Vol. 1 No. 21, Special Issue - December 2011. 